\title{
PENGEMBANGAN GAME KOGNITIF PROAKTIF SEBAGAI METODE EDUKASI PERNIKAHAN DINI PADA REMAJA
}

\section{PROACTIVE COGNITIVE GAME DEVELOPMENT AS A METHOD FOR EARLY MARRIAGE EDUCATION TOWARDS TEENAGERS}

\author{
Masturoh $^{1 凶}$, Adrestia Rifki Naharani², Natiqotul Fatkhiyah ${ }^{3}$ \\ Program Studi D III Kebidanan, Universitas Bhamada Slawi \\ Jl. Cut Nyak Dien, Kalisapu, Slawi, Kab. Tegal, Indonesia \\ Correspondent Email: masturoh87@gmail.com
}

\begin{abstract}
ABSTRAK
Pernikahan dini menjadi suatu fenomena yang mempunyai dampak yang kompleks dan Indonesia menjadi ranking kedua di ASIA setelah Kamboja. Salah satu faktor penyebab penikahan dini adalah kurang nya pengetahuan masyarakat khususnya remaja tentang pernikahan dini. Sehingga perlu adanya metode edukasi yang tepat bagi remaja untuk meningkatkan pengetahuan pernikahan dini. Metode edukasi game kognitif proaktif merupakan salah satu cara pendekatan edukasi kesehatan reproduksi dan seksualitas pada remaja. Prinsip kognitif proaktif adalah dilakuakan dengan mengajak pemuda berpartisipasi menyebutkan hal postif dan negatif tentang pernikahan dini pada pemuda secara proaktif, sampai bisa menyimpulkan sendiri masalah tersebut itu baik atau tidak jika dilakukan oleh pemuda. Penelitian ini bertujuan untuk mengetahui keefektifan game kognitif proaktif yang digunakan sebagai metode edukasi dampak pernikahan dini. Penelitian ini menggunakan disain Pre experiment design dengan one grup pre test - post test, dengan uji statistic non parametrik Wilcoxon signed rank test serta jumlah subyek sebanyak 35. Hasil penelitian menunjukan bahwa terdapat peningkatan pengatahuan yang signifikan yaitu sebesar 34,17 setelah dilakukan game kognitif proaktif pada subyek. Hasil Analisa menunjukan game kognitifif proaktif efektif sebagai metode edukasi dampak pernikahan dini pada remaja dengan nilai $p=$ $0,001(<0,005)$
\end{abstract}

Kata Kunci : game kognitif proaktif; pernikahan dini; edukasi; remaja

\begin{abstract}
Early marriage is a phenomenon that has complex impacts and Indonesia is ranked second in Asia after Cambodia. One of the factors causing early marriage is the lack of public knowledge, especially teenagers, about early marriage. The right educational method for teenagers is expected to increase knowledge of early marriage. The proactive game education method is one way to approach reproductive health and sexuality education in adolescents. The cognitive principle is carried out by inviting youth participation to participate in positive and negative things about early marriage proactively, concluding for themselves that the problem is good or not if it is done by youth. This study was aimed to determine the effectiveness of proactive cognitive games used as an educational method for the impact of early marriage. This study used a preexperimental design with one group pre-test - post-test, with a non-parametric Wilcoxon signed rank test and 35 subjects. The results showed that there was a significant increase in knowledge that was 34.17 after a proactive cognitive game was performed. on the subject. The results of the analysis showed that proactive cognitive games were effective as an educational method for the impact of early marriage on adolescents with $p$ value $=0.001(<0.005)$.
\end{abstract}

Keywords: proactive cognitive game; early marriage; education; teenagers 


\section{PENDAHULUAN}

Menikah merupakan bagian dari tahapan kehidupan seseorang yang diharapkan akan mendapat kebahagiaan. Oleh karena itu pernikahan perlu adanya persiapan yang matang baik fisik maupun psikologis. Pernikahan tanpa persiapan yang matang, seperti pernikahan dini akan menimbulkan dampak yang negatif (Kiwe, 2019). Fenomena pernikahan dini pada remaja mempunyai dampak yang cukup kompleks. Di Indonesia termasuk negara dengan presentase pernikahan usia muda tertinggi di dunia ranking 37 dan tertinggi ke dua di ASIAN setelah kamboja. Berdasarkan data profil anak Indonesia tahun 2018, menyatakan bahwa perempuan di indonesia dengan usia 10-17 tahun pernah menikah diusia 15 tahun sebanyak 39,17\%, 37,91\% kawin diusia 16 tahun dan 22,92\% kawin diusia 17 tahun (Kemenppa RI, 2018). Sosialisasi pentingnya perkawinan di usia yang tepat perlu dilakukan oleh kementerian dan lembaga kepada masyarakat. Perlu dikomunikasikan pentingnya mengatur usia perkawinan khususnya bagi perempuan. Menikah di usia yang tepat akan mengurangi resiko kematian ibu dan bayi. Dalam jangka panjang, hal ini juga akan menurunkan angka fertilitas yaitu memperpendek rentang masa reproduksi perempuan melalui penundaan usia perkawinan (Kemenppa RI, 2018).

Adapun penyebab terjadinya pernikahan dini meliputi facto budaya, adat istiadat, orangtua, ekonomi, pendidikan, dan faktor dari dalam diri individu (Hardianti \& Nurwati, 2020). Pernikahan dini merupakan pernikahan yang dilakukan oleh seorang yang pada hakikatnya kurang mempunyai persiapan, kematangan baik secara biologis, psikologis maupun secara sosial ekonomi. Pernikahan dini dapat di definisikan sebagai ikatan lahir batin antara seorang pria dan wanita sebagai suami istri yang masih muda atau remaja (Sekarayu \& Nurwati, 2021).
Berdasarkan data Kantor Kementrian Agama Kabupaten Tegal tahun 2019 terdapat wanita menikah usia kurang dari 19 tahun sebanyak 80 orang, meningkat meningkat $23,75 \%$ dari tahun 2018. Daerah dengan perkawinan dini terbanyak adalah kecamatan Adiwerna dengan prosentase 37,50\% (30 pasang) (Kementrian Agama Kabupaten Tegal, 2019).

Dampak pernikahan dini dibagi menjadi 3 yaitu, dampak psikologis, kesehatan dan sosial ekonomi. Dampak psikologis yang bisa muncul diantaranya mudah emosi, stress dan terbebani. Dari segi kesehatan alat reproduksi perempuan yang belum siap akan mengakibatkan kelahirkan prematur. Selain itu pernikahan dini juga berdamak pada sosial ekonomi yaitu kurangnya bersosialisasi dengan masyarakat, malu karena putus sekolah dan masih bergantung pada orang tuanya (Maudina L, 2019).

Metode edukasi game kognitif proaktif merupakan salah satu cara pendekatan edukasi kesehatan reproduksi dan seksualitas pada remaja. Edukasi ini dilakukan dengan permainan partisipasi diskusi satu kasus tentang permasalahan reproduksi atau penyimpangan seksual dengan prinsip kognitif-proaktif (Taukhit, 2014).

Edukasi ini dilakukan dengan permainan partisipasi diskusi satu kasus tentang pernikahan pada usia dini dengan prinsip koginif proaktif. Prinsip kognitif proaktif adalah dilakuakan dengan mengajak pemuda berpartisipasi menyebutkan hal postif dan negatif tentang pernikahan dini pada pemuda secara proaktif, sampai bisa menyimpulkan sendiri masalah tersebut itu baik atau tidak jika dilakukan oleh pemuda (Taukhit, 2014).

Menurut Fitria dan Nurfurqoni (2020) permainan eduksi kognitif proaktif memiliki pengaruh terhadap pengetahuan remaja tentang pernikahan dini (Fitria et al., 2020). 
Penelitian ini bertujuan untuk mengetahui keefektifan permainan kognitif pro-aktif yang digunakan sebagai metode edukasi dampak pernikahan dini. Metode permainan edukasi proaktif dengan melibatkan sumber ahli yang diharapkan dapat menguatkan pemahaman remaja tentang pernikahan dini pada remaja.

\section{METODE PENELITIAN}

Penelitian ini menggunakan disain Pre experiment design dengan one grup pre test - post test yang merupakan desain penelitian eksperimen yang memiliki karakteristik sampel tidak diambil secara random tapi menggunakan sampel kelompok, kelompok yang digunakan hanya satu kelompok sehingga desain penelitian ini tidak memiliki kelas control (Ismail Fajri, 2018). Kriteria inklusi penelitian ini adalah remaja usia 12 20 tahun dan anggota karang taruna Desa Adiwerna Kabupaten Tegal yang hadir di tempat penelitian. Sedangkan Kriteria eksklusi nya adalah remaja usia 21 tahun dan anggota karang taruna yang tidak hadir di tempat penelitian. Penelitian ini menggunakan 1 kelompok dengan jumlah 36 responden), Tehnik sampling yang digunakan adalah insidental sampling, dimana semua yang hadir dijadikan responden.

Pelaksanaan penelitian yaitu responden diberikan pre test, setelah itu responden diberikan perlakuan permainan kognitif pro aktif, dan setelah itu diberikan post test dengan kuesioner yang sama. Metode yang digunakan adalah metode survei pada remaja di karang taruna desa Adiwerna Kabupaten Tegal dengan menggunakan kuesioner terstruktur. Sebelum data dilakukan uji statistic, data perlu dilakukan uji normalitas data Uji normalitas data kali ini menggunakan Kolmogorov smimov karena menggunakan data 1 sampel. Hasil uji normalitas data pada penelitian ini adalah nilai signifakansi 0,001 yang berarti bahwa data berdistribusi tidak normal. Data yang diperoleh kemudian dianalisis dengan metode statistic non parametrik Wilcoxon signed rank test karena data berdistribusi tidak normal.

\section{HASIL}

\section{Karakteristik Subyek}

Remaja merupakan peralihan dari masa anak-anak menuju dewasa (Syamsu K, 2021). Menurut Monk dkk (2002) dalam Fakhrurrazi (2019) masa remaja terjadi pada usia 12 sampai 21 tahun, dengan pembagian remaja awal umur 12 - 15 tahun, remaja pertengahan umur 15 - 18 tahun dan remaja akhir umur 18 - 21 tahun (Fakhrurrazi, 2019). Berdasarkan tabel 1.1 penelitian ini subyek terbagi menjadi 3, yaitu remaja awal (12-15 tahun) 2,86\%, remaja pertengahan (> 15-18 tahun) $54,28 \%$ dan remaja akhir (>18-21 tahun) $42,86 \%$. Berdasarkan dari subyek yang ada sudah memenuhi kriteria penelitian.

Game Kognitif Proaktif

Tabel 1. Karakteristik Subyek berdasarkan Umur

\begin{tabular}{lcc}
\hline \multicolumn{1}{c}{ Kategori Remaja } & Jumlah & $\begin{array}{c}\text { Presentase } \\
\text { (\%) }\end{array}$ \\
\hline Remaja Awal & 1 & 2,86 \\
\hline Remaja Pertengahan & 19 & 54,28 \\
\hline Remaja Akhir & 15 & 42,86 \\
\hline Total & 35 & 100 \\
\hline
\end{tabular}


Dalam penelitian ini subyek diajak berpartisipasi terlibat secara aktif dan mampu mengutarakan pendapatnya dalam menyebutkan dampak positif dan negative pernikahan dini pada remaja dengan teknik mengisi "pohon harapan" yang didampingi oleh fasiltator. Berikut gambaran hasil dari game konitif proaktif

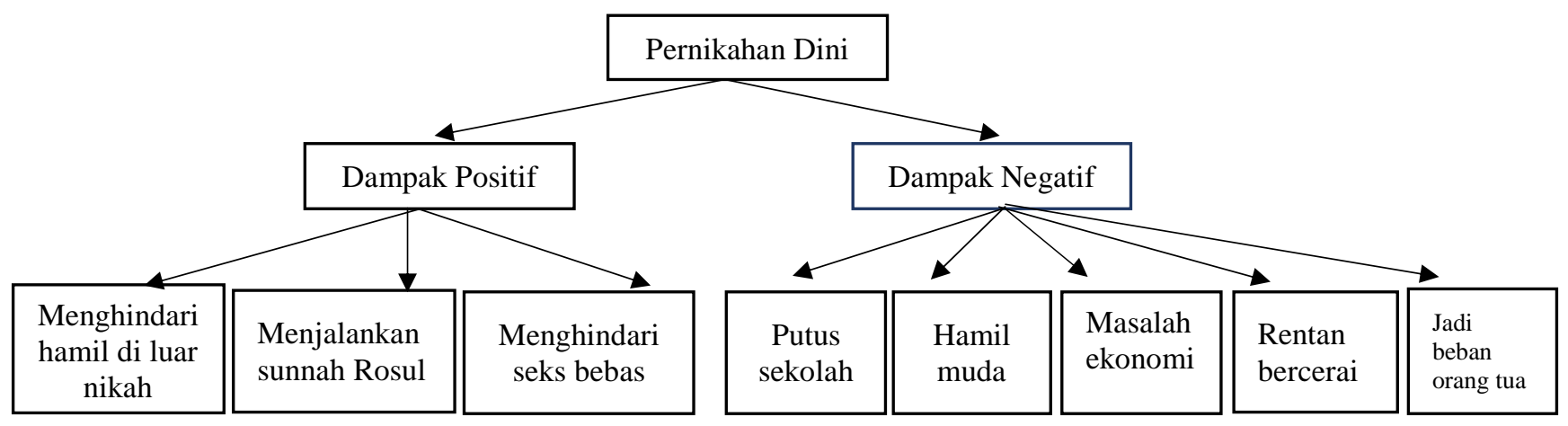

Gambar 1. Pohon Harapan pada Game Kognitif Proaktif

Pengetahuan Dampak Pernikahan Dini

Peningkatan yang signifikan terhadap pengetahuan subyek yaitu pada kategori baik dari $20 \%$ menjadi $57,14 \%$. Pada ketegori cukup terjadi penurunan yaitu dari $54,29 \%$ menjadi 42,86\%. Sedangkan setelah game kognitif proaktif tidak ada subyek yang memiliki pengetahuan kurang (0\%) dari total 35 subyek. Game kognitif proaktif merupakan salah satu cara memberikan pendidikan kesehatan yang efektif. Pendidikan Kesehatan merupakan merupakan upaya untuk meningkatkan perilaku hidup sehat.

Tabel 2. Distribusi Frekuensi Pengetahuan Dampak Pernikahan dini

\begin{tabular}{ccccc}
\hline \multirow{2}{*}{$\begin{array}{c}\text { Kategori } \\
\text { Pengetahuan }\end{array}$} & \multicolumn{4}{c}{ Katagori Pengetahuan } \\
\cline { 2 - 5 } & Pre perlakuan & \multicolumn{2}{c}{ Post perlakuan } \\
\hline Baik & 7 & 20,00 & 20 & 57,14 \\
\hline Cukup & 19 & 54,29 & 15 & 42,86 \\
\hline Kurang & 9 & 25,71 & 0 & 0 \\
\hline Total & 35 & 100 & 35 & 100 \\
\hline
\end{tabular}

Hasil penelitian pengembangan game kognitif proaktif sebagai metode edukasi pernikahan dini memiliki nilai $p$ 0,001, yang berarti bahwa game kognitifif proaktif efektif sebagai metode edukasi dampak pernikahan dini pada remaja. Pada hasil uji statistik menunjukan adanya peningkatan pengetahuan mengenai dampak pernikahan dini sebanyak 21 subyek setelah dilakukan game kognitif proaktif dan tidak ada penurunan pengetahuan setelah dilakukan game kognitif proaktif. Tetapi terdapat nilai yang sama setelah game kognitif proaktif sebanyak 14 subyek. Selain itu juga terdapat 4,49 kali lebih besar peningkatan pengetahuan setelah mengikuti game kognitif proaktif. 
Tabel 3. Analisi game Kognitif Proaktif sebagai Metode Edukasi Dampak Pernikahan Dini pada Remaja

\begin{tabular}{l|lccc}
\hline \multicolumn{1}{c|}{ Variabel } & & $\mathbf{N}$ & $\mathbf{Z}$ & $\mathbf{P}$ \\
\hline Pengembangan game kognitif & Negative Ranks & 0,0 & $-4,491$ & 0,001 \\
\cline { 2 - 6 } $\begin{array}{l}\text { proaktif sebagai metode } \\
\text { edukasi dampak pernikahan } \\
\text { dini pada remaja }\end{array}$ & Positive Ranks & 21,0 & & \\
\cline { 2 - 6 } & Ties & 14,0 & & \\
\cline { 2 - 6 } & & 35 & & \\
\hline
\end{tabular}

\section{PEMBAHASAN}

Remaja merupakan masa ingin tahu banyak hal. Oleh karena itu metode pembelajaran yang digunakan juga harus sesuai dengan perkembangan masa remaja, yaitu metode diskusi untuk menerima suatu kesimpulan dan tidak kaku dalam penyampaian materi (Taukhit, 2014). Metode edukasi game kognitif-proaktif merupakan salah satu cara edukasi yang efektif pada remaja, dalam hal ini adalah dampak pernikahan dini pada remaja. Prinsip game kognitif proaktif yaitu mengajak partisipasi remaja dalam permainan dengan cara diskusi tentang permasalahan yang akan dibahas (Taukhit, 2014). Remaja tidak lepas dari kesehatan reproduksi, karena remaja merupakan awal dari proses reproduksi seseorang (Sekarayu \& Nurwati, 2021). Pendidikan Kesehatan reproduksi pada remaja dengan metode kognitif proaktif memfokuskan pada partisipasi atau terlibat katif (ranak proaktif) serta mengutarakan pendapat tentang suatu topik (ranah kognitif).

Hasil dari pengindraan seperti penglihatan, pendengaran, penciuman, rasa dan raba disebut pengetahuan. Pengetahuan merupakan ranah kognitif yang sangat penting dalam membentuk perilaku seseorang. Ranah kognitif dapat diukur melalui wawancara atau angket yang berisi pertanyaan mengenai materi yang akan diukur (Nurmala, 2018).

Pernikahan dini merupakan pernikahan yang terjadi di bawah umur, dan belum siap secara fisik dan psikologis (Fitria et al., 2020). Menurut Undang-undang perlindungan anak no. 23 tahun 2012 pernikahan dini merupakan pernikahan yang terjadi pada usia dibawah delapan belas tahun. Usia ideal untuk menikah bagi perempuan yaitu 20 tahun dan 25 tahun untuk laki-laki (Kiwe, 2019). Pernikahan dini dapat menimbulkan dampak, tapi dampak pernikahan dini lebih banyak dialami oleh perempuan. Secara garis besar dampak pernikahan dini dibagi menjadi 3, yaitu Kesehatan, psikologis dan sosial ekonomi. Dampak psikologis yang bisa muncul diantaranya mudah emosi, stress dan terbebani. Dari segi kesehatan alat reproduksi perempuan yang belum siap akan mengakibatkan kelahiran prematur. Selain itu pernikahan dini juga berdamak pada sosial-ekonomi yaitu kurangnya bersosialisasi dengan masyarakat, malu karena putus sekolah dan masih bergantung pada orang tuanya (Maudina L, 2019).

Dalam penelitian ini dilakukan game kognitif proaktif pada remaja mengenai dampak pernikahan dini. Berdasarkan tabel 2.3 menunjukan bahwa game kognitif proaktif dinyatakan efektif sebagai metode edukasi dampak pernikahan dini pada remaja dengan nilai $p=0,001$. Metode ni melibatkan keaktifan dari responden, dimana responden menyebutkan dampak positif dan negative berdasarkan pengatahuan responden, yang kemudian dievaluasi oleh narasumber, sehingga setelah permainan responden lebih memahami tentang dampak dari pernikahan dini. Hal tersebut sesuai dengan hasil penelitian Fitria dan Nurfurqoni (2020) yang menyatakan bahwa terdapat pengaruh antara Pendidikan kesehatah dengan metode kognitif proaktif terhadap pengetahuan dampak pernikahan dini pada remaja. Selain itu penelitian juga dilakukan oleh Suryafma F (2020) dengan hasil 
terdapat pengaruh antara edukasi Kesehatan reproduksi dan seksual dengan metode kognitif proaktif dalam peningkatan pengetahuan persiapan masa prakonsepsi bagi remaja (Suryafatma, 2020).

\section{KESIMPULAN}

Pendidikan Kesehatan reproduksi pada remaja sangat penting, termasuk mengenai pernikahan dini. Diperlukan adanya suatu metode untuk menyampaikan materi dengan efektif. Game kognitif proaktif sebagai metode edukasi dampak pernikahan dini teruji efektif. Sehingga perlu diterapkan nya metode tersbut pada sub pembahasan yang lain pada Pendidikan Kesehatan reproduksi remaja.

\section{REFERENSI}

Fakhrurrazi. (2019). 1. Karakteristik Anak Usia Murahiqah. Al-Ikhtibar: Jurnal IImu Pendidikan, 6(1), 573-580. https://doi.org/10.32505/ikhtibar.vol6i1. pp60

Fitria, D., Nurfurqoni, F. A., \& Bandung, P. K. (2020). The Effect Of Health Education With Proactive Cognitive Game To Teenager Knowledge About. 12(2), 403-409. https://doi.org/10.34011/juriskesbdg.v1 2i2.851

Hardianti, R., \& Nurwati, N. (2020). Faktor Penyebab Terjadinya Pernikahan Dini Pada Perempuan. Fokus: Jurnal Pekerjaan Sosial, 3(2), 111-120.

Ismail Fajri. (2018). Statistika untuk Penelitian Pendidikan dan IImu-IImu Sosial. Jakarta: Prenadamedia Grup Kementrian Agama Kabupaten Tegal. (2019). Data Usia Menikah Calon Pengntin
Kemenppa RI. (2018). Profil Kesehatan Anak Indonesia Tahun 2018. IImu Pendidikan, 5(1), 12-21.

Kiwe, L. (2019). Mencegah Pernikahan Dini. In Jurnal HARKAT Media Komunikasi Gender (Vol. 15, Issue 2).

Maudina L. (2019). Dampak Pernikahan Dini Bagi Perempuan. HARKAT Media Komunikasi Gender, 15(2), 7.

Nurmala, dkk. (2018). Promosi Kesehatan. Surabaya: Airlangga University Press

Nuryadi, dkk. (2017). Dasar-Dasar Statistik Penelitian. Yogyakarta : Sibuku Media

Satriyandari, dkk. (2020). Pernikahan Dini Usia Remaja. Yogyakarta : Universitas Aisyiyah Yogyakarta

Sekarayu, S. Y., \& Nurwati, N. (2021). Dampak Pernikahan Usia Dini Terhadap Kesehatan Reproduksi. Jurnal Penelitian Dan Pengabdian Kepada Masyarakat (JPPM), 2(1), 37. https://doi.org/10.24198/jppm.v2i1.334 36

Suryafatma, F. (2020). ... Seksual Dengan Metode Kognitif Proaktif Dalam Peningkatan Pengetahuan Persiapan Masa Prakonsepsi Bagi Remaja Putri Di Sman 6 http://scholar.unand.ac.id/61709/

Syamsyu Khairunnisa. (2021). B-Kespro (Bimbingan Konseling Kesehatan reproduksi) Remaja. Jakarta: Media Sains Indonesia

Taukhit. (2014). Pengembangan Edukasi Kesehatan Reproduksi dan Seksualitas Remaja dengan Metode Game Kognitif Proaktif. Jurnal Studi Pemuda, 3(2), 123-132. https://jurnal.ugm.ac.id/jurnalpemuda/a rticle/view/32028 